\title{
NECESSITY OF TRANSFORMATION POLITICAL INTO THE ECONOMIC STATE
}

\author{
Maja Anđelković ${ }^{1}$, Dragana Radosavljević ${ }^{2}$, Vladana Lilić ${ }^{3}$ \\ ${ }^{1}$ PhD, full professor, Faculty of Informatin Technology and Engineering, Union - Nikola Tesla \\ University, Belgrade, Serbia \\ ${ }^{2}$ PhD, full professor, Faculty of Business Studies and Law, Union - Nikola Tesla University, Belgrade, \\ Serbia \\ ${ }^{3}$ MA, lecturer, Faculty of Business Studies and Law, Union - Nikola Tesla University, Belgrade, \\ Serbia
}

\begin{abstract}
From the emergence of the state as an institute to the present day, its goals and concepts of functioning have remained more or less the same and have been reduced to organizing authority and population for defense against other tribes, later nations, but also to hold in obedience their subjects, i.e. those who are gave their rulers the mandate to govern on their behalf a unity called the state.

States in modern conditions still function on the basis of the past, i.e., the past centuries. Instead of solving, the modern state produces problems and is unable to respond to new challenges and changes that occur both in the natural and social order. Evidence for this is obvious, ranging from environmental, political and social problems to migration, crises that are becoming more and more devastating, war conflicts, strikes and general discontent at national or global levels.

In this context, the state creates mechanisms to maintain the status quo and extend the powers of the elected. Democracy, human rights protection, numerous global or regional declarations have become the subject of interpretation, as well as their disrespect, and even abuse. The trend of widening the gap between the poor and the rich is increasing, war conflicts have been waged in certain countries for years, many have been devastated, filled with huge amounts of poison that destroys the resource of water, land and air. Instead of great politicians and leaders like Roosevelt, De Gaulle, Churchill, political leaders and party officials who are hard to leave power and who are struggling to stay in power and rule for a long time, are on the scene.
\end{abstract}

In a word, the modern state is unable to respond to a numerous challenges, because it has retained the same mechanisms and concepts of governance as $i n$ the last century, and in many countries even from the time of the feudal age. Establishing force-based organizations, enacting laws, tax and parafiscal burdens to sustain party bureaucracy, feuds and enrichment on the one hand, and poverty and misery on the other, are visible in much of the world, indicating problems in the functioning of the state and government.

Indicated condition can be improved by transforming a traditional political state into an economic state, whose priority goal would be to ensure a satisfactory quality of life and sustainable development. Thus, the state would focus on the people i.e. population, rather than the ideological political platform of the party in power.

The paper indicates current issues of the functioning of the modern state and problems that are produced by the modern state.

Keywords: state, political state, economic state, state is the same as enterprise.

JEL Classification: H10, H19

Formulas: 0; fig.: 0; tabl.: 0; bibl.: 5 .

Introduction. The classics of Marxism, which are mostly forgotten, were written about the state as an institution and organization, but their sayings and teachings were marginalized to such an extent that in the knowledge society, the state retained all the prerogatives of a feudal and, in some elements, slave state. 
The much-forgotten Marx, Engels, and Lenin were eliminated from the social sciences, leaving no knowledge of the brilliant analysis and argumentation of what a state really is, its place, importance, and role in organizing and managing a shared life and work.

The epilogue of the above is visible, namely, that the state has risen above society, that it has become a force unto itself, and that it is in the function of the ruling class, i.e. the party in power. It is not disputed, and on that pointed the classics of Marxism, that "the state is the product of the irreconcilability of class opposites, it arise there, then and when class opposites cannot objectively be reconciled. And vice versa: the existence of the state proves that class opposites are irreconcilable. (Lenin:1918, p.12)

Although the state is an organ of class rule, opponents of Marxism and defenders of the state say that it is an organ of reconciliation, or reconciliation of class, forgetting the realization of Marxism that "the state could neither emerge nor sustain itself if class reconciliation were possible." Thus, according to Marx, the state is "an organ of class rule, an organ of oppression of one class by another; it is the creation of an order that legitimizes and reinforces that oppression, alleviating class conflicts." In other words, the state is a class creation that cannot be "reconciled with its antipode, or the class opposite to it."

The state is also treated as an institution that should ensure the welfare of the nation by creating the political, legal, institutional, economic and other conditions for this to happen. Well-known theorist Norman Barry points out that "the state must not lead us to think that it is an entity with a will that is superior to the will of its citizens." It boils down that the purpose of its existence for the sake of pursuing the interests and satisfaction of citizens and its will should not distinguish it from the will of the citizens. (Barry: 2007, p. 88)

More than a hundred years have passed since the stated statements. Societies and states have experienced and are constantly experiencing changes in all spheres of social and economic life. Fundamental and radical social, political, economic, technological, cultural and other changes have taken place, but the basic pattern of behavior and functioning of the state has survived. The following can be drived from above: something is probably valuable if it lasts for more than a century. To this should be added another alpha plus, namely that the influence of the state as an institution on global level has expanded to such an extent that it is alienating itself from society and becoming a goal and purpose in itself, and that the rulers elected by the will of the people seek to longer retain power and achieve their personal goals and interests. Thus, the state and the government primarily work for the personal, and neglect the general national interests.

Literature Review. The study of the basic tendencies of modern political management of the state is presented in the following scientific works: Braun L. (1979) in "World without borders", Beri N. (2007) in "Introduction to modern political theory", Blanchard K. (2007) in "Management at the higher level", 
Engels F. (1979) in "The Origin of the Family, Private Property and State", Lenin V. (1918) in "The State and the Revolution" and other authors.

Aims. The purpose of this study is to study the main trends of transformation of political governance into economic governance.

Methods. The author used the methods of static and logical comparison, systematization and generalization, which made it possible to achieve the goal of the study.

Results. The study of the basic trends of modern political management of the state helped to distinguish the following stages:

- the end of the political and necessity for the emergence of an economic state;

- the state is the same as a enterprise.

The end of the political and necessity for the emergence of an economic state. The state is necessary political institution for every society. Together with church organizations, it represents the first organized modalities of people's life and work, as it has been shown that living and working together is impossible without directing individuals toward common goals. Initially, it was important for the state as an institution to ensure the protection and survival of population, so that today its function is to ensure the quality of life of the population, which is expressed through economic freedoms, as condition for creation of political and other freedoms.

It is shown that the modern state in many elements is not in function of citizenship and achievement of political, i.e. economic goals of the population. It is becoming increasingly alienated and an institution that stands above the people as the sole sovereign, to abuse certain institutions and direct them against the people, to create and strengthen ministries of forces and coercion, which oppose the people in the case of dissatisfaction and reaction to an inefficient state and its institutions. It is paradoxical, but true, for the state to do so today, when human rights are highlighted and numerous declarations are made to promote the rule of law, or to protect the population from the state. Of course, at the global as well as at the national level, there are organizations that should protect the population from the state and limit its power, promote human rights and freedoms, and intercede and participate in their realization.

Controversy over the state has also been based on the practice of some European states in wich no government was formed for many years, and the state functioned as it would under normal political conditions. The practice of some international companies has shown that by eliminating management from company systems productivity is significantly improved, absences and delays in employees are reduced, interpersonal relationships have also been improved, which is a symptom that management structures are a problem, especially if they "rise" above employees. Therefore, no organization, even the state, can survive if it is not successfully managed, but mismanagement can jeopardize the survival of any organization, regardless of its natural and social potential. 
This indicates that the state has become alienated and increasingly is alienated and does not serve the purpose for which it has existed for centuries. The classics of Marxism saw a way out of this, in the revolution and in organizing the rebellion of the masses. The problem is that the change of government does not eliminate the oppression and subjugation of the people, because the concepts of leadership and governance do not change. The Brazilian revolutionary Paul Freire also points to this fact: "When the oppressed overthrow those who oppress them, the only model of leadership they have left is the model of leadership used by their oppressors. In this way, the oppressed become the oppressors. The consequences are devastating not only for the state, but for any organization" (Blanchard: 2007, p. XVIII).

The above points out that the transformation of the state from political to economic cannot be accomplished without changing governance and without introducing new concepts and styles of governance and leadership, as well as changing the consciousness of the people, because it is difficult or impossible to change the state without changing the population. This means that it is necessary to put the state in a different context, that is, transformation from the role of keeping the oppressed class in obedience, into an institution that will work to raise the quality of life and to serve the sustainable development of the world, or national communities. This is possible by understanding the state as any other organizational system, i.e. as a company from the real sector or family, by treating the prime minister as the host or CEO, and the parliament as a tribal, or family council, or shareholders assembly in corporate systems.

These findings can be questioned, using the arguments of simplification and identifying the organization and management of the state with business and corporate systems, and that the state is more extensive and complex, that it has a different role and different tasks. It can be particularly objected that the management of the state, religious and military organizations represented significant experience in the management of business organizations, and that it is illusory in modern conditions to go back to the inverse in which the state would assume the experience of managing corporate systems.

Nevertheless, precise analyzes show the usefulness of mentioend inversion, i.e. that states assume certain design and management modalities from transnational and multinational corporations and seek to ensure the functioning of the state on a corporate basis. It turns out that business organizations of an international character operate in markets that are turbulent and increasingly resemble war scenes. Survival in these markets is much more difficult nowadays due to increasing competition and rapid but uncertain changes. In such circumstances, learning how to manage and operate company organizations may be of use to the state to apply their experience of achieving primarily economic goals as a condition for achieving all other goals.

The state is the same as a enterprise. For a long time, even today, the state is considered to be an institution mainly and predominantly engaged in political and legal sciences. It is seen as a political institution exercising power, 
but also a legitimate institution of rule and coercion. Marxism theorists have also written about the state and viewed it as a class creation. The stateses were created with the emergence of classes and will disappear when classes, opposites and conflicts vanish. Marx defines the state as "an organ of class rule, an organ of oppression of one class by another; it is the creation of an order that legitimizes and reinforces that oppression, alleviating class conflicts." Engels points out that the essence of the state is to mitigate conflicts, i.e. to keep conflicts between classes and opposites of economic interests, within the limits of order. As such, the state is placed above society, which is increasingly alienated from it." (Engels: 1979, p. 177)

The classics of Marxism have been largely forgotten, although they have given the best analysis of the functioning of the capitalist political system, which is still relevant today, but instead of classses it is about political options, ideologies and parties. In the broader context, conflicts between individual political options, i.e. parties in power and those not participating in governance, are in the economic interests. Those in power manage state potentials, and thereby derive some economic effects, and political options non-participating in power are exercising the consequences that follow.

The aforementioned raises the question of why the state is not concerned with the economic sciences as well, because it is difficult to talk about any institution unless it is about the economic dimension, as crucial in the performance of every activity, but also as the basic meaning in the existence of any state, religious, humanitarian or business organization and institution. In other words, modern economic science is not sufficiently concerned with the state as an institution, which has led the state to function at the present time, in the way it functioned in a feudal society, i.e. in the agrarian or industrial era.

The epilogue is clear, and this is a state today unable to meet the challenges that are emerging at the global, or national, and corporate levels. Numerous conflicts and wars, devastation of individual states, interstate tensions, wave of migration, economic crises confirm this unequivocally. How obvious it is that the role of the state as a political institution is marginalized, it can be seen that there are states that did not have their own governments or governors for a long period of time, and that the economy and society as a whole were functioning well.

It turns out that the states have not adapted their business and functioning to modern conditions and that they often produce problems themselves, instead of preventing them, and when they emerge to solve them as soon as possible and with quality.

The undisputed fact is that the modern state should be rather an economic, then a political institution, and it should be primarily concerned with economic science, since its primary task should be to improve the standard of living, that is, the quality of life of the population, to ensure a longer life span of population and provide conditions for reproduction and maintenance of the population. All 
other tasks, or goals, are derived from these or rely on them, which is often neglected.

In order for this to happen, it is necessary to understand the state as an enterprise with clearly defined goals, which has its potentials (material, human, information, financial and others) with which it has to realize the set goals, but with the least economic sacrifices. In other words, the state, like any other business organization, has its institutional foundations, legal framework, resources and other as prerequisites for the survival, growth and development of the country. It, as well as the company, has its own inputs, transformation processes with the general attitude that with the smallest possible inputs, maximize the outputs and effects. If the state is not guided by the stated economic principles and logic, i.e. if the effects are not satisfactory and the state is showing a negative financial result (which means that it is spending inadequately) - as such, state should be monitored, and ultimately it should experience the fate of any other enterprise.

Discussion. However, so far, it has not happened that the state went bankrupt and its structures experienced the fate of corporate employees. It is shown that the decisions of individual multinationals can go beyond national significance, i.e. "the decisions of a multinational corporation may affect the well-being of people in a particular country more than the decisions of their government" (Brown: 1979, p. 286).

Citizens, that is, the population within a state, should be understood as shareholders engaged in particular businesses, investing labor, energy and allocating funds for the maintenance of state administration, as well as maintaining public institutions and meeting common needs. Citizens, such as shareholders in a company, should choose the organizations or parties that will best achieve their interests and goals, but who will also change and sanction them if they do not achieve their interests and expectations. Like an enterprise, citizens need to set the concept of the state, that is, to calculate how much it costs, what services it provides and what is the quality of its services, so that the input parameters for creating the state budget could be planned.

Conclusion. The analysis has shown and proved that there is room for thinking about the state and its institutes and the way they function in a different way from what has been written in textbooks and other literature from the past, but also when it comes to contemporary political theory. The world has undergone radical changes over the last few decades, with political systems remaining at the level of the industrial and, in some countries, the agrarian age. The general characteristic of modern civilization is that it is in the society of knowledge, robotics and artificial intelligence, and that political life has been going on the same way as centuries ago.

This disproportion has a negative impact on the general social and economic development of countries, especially those in transition. The state does not produce. It spends and directs its main activities on tax collection or by organizing a public economy on the way that is used as its own and kept as 
someone else's. Treating the state as a political institution, that is, neglecting economic principles and business economics, leads to politics becoming the largest and most profitable business, which again amounts to the economic dimension. It turns out that it is nowhere near easier, faster, or more profitable to make a fortune than in politics, especially when it comes to countries in transition, resulting in the struggle for power becoming similar to the pursuit of classic fighting, that is, fighting for life or death.

The paper partly points to the necessity of transformation of classical state based on classical political theory into an economic state whose basic or one of the basic goals and tasks is to provide citizens with a longer lifespan, a better quality of life and work and reproduction of a species, i.e. nation. This puts at the forefront the economic dimension of organizing and managing the state, as a condition of the existence of all other functions, which is best achieved through the observation of the state as an enterprise that creates new values. This is a realistic analogy, because many modern corporations are economically stronger than some mid-developed countries, have the knowledge and experience in managing large asset values and they achieve significant success in turbulent market conditions.

Some of the findings, suggestions and ideas that the authors argue in this paper are likely to depart from existing political thought and practice, but it should be borne in mind that all ideas were initially disputed and, over time, with modification gained in importance. The paper raises more questions than answers, which means that it leaves enough room for criticism, disputation, or upgrade, which contributes not only to the advancement of practice, but also to the theoretical framing of this issue.

Author contributions. The authors contributed equally.

Disclosure statement. The authors do not have any conflict of interest. References:

1. Braun, L., (1979). Svijet bez granica, Globus, Zagreb.

2. Beri, N., (2007). Uvod u modernu političku teoriju, Službeni glasnik, Beograd.

3. Blanchard, K., (2007). Rukovođenje na višoj razini, Mate, Zagreb.

4. Engels, F.,(1979). Poreklo porodice, privatne svojine i države, BIGZ, Beograd.

5. Lenjin, V., (1918). Država i revolucija, BIGZ, Beograd.

Received: December 06, 2019 